\title{
Harmonization of Law on Mutual Legal Assistance by Indonesia in Eradicating Transnational Economic Crime in ASEAN Economic Community
}

\author{
Yoserwan $^{1, *}$ \\ ${ }^{1}$ Criminal Law Department, Faculty of Law, Universitas Andalas \\ ${ }^{*}$ Corresponding author. Email yoserwan@law.unand.ic.id
}

\begin{abstract}
The establishment of the ASEAN Economic Community is aimed at increasing prosperity in the region. However, there are challenges and threats to achieving that goal. One of the serious threats in achieving the goals of the ASEAN Economic Community is Transnational Crime especially in economic activities that cause crime. As anticipation, ASEAN has agreed to a Treaty on Mutual Legal Assistance in Criminal Matters (ASEAN MLA). This agreement has been ratified by all member countriesAll member countries have ratified this agreement. The objective of the Treaty is to improve the effectiveness of the law enforcement authorities of the Parties in the prevention, investigation, and prosecution of offenses through cooperation and mutual legal assistance in criminal matters. However, the Treaty has not optimally functioned in fighting transnational crime. It is proved from the fact that the request for legal assistance between member countries is relatively low. The differences in the legal system of member countries have become a major obstacle to implement the Treaty. That is why OECD recommended that there should be better coordination in legal enforcement agencies between or different legal systems. This article is discussing the harmonization of laws regarding MLA in combating transnational crime in ASEAN Countries. The research applies legal research and analysis laws both at the national and international levels. The research finds that the sovereignty principle becomes the primary handicap in achieving harmony in the laws since each country places national interest as the priority. Disharmony is found in the limitation of the scope of the agreement and in the dual criminality principle that causes each national law to limit the crime that is covered by the agreement. There is also an escape clause that causes a member state to refuse a request from another country. To optimize transnational crime eradication, there should be an effort to increase harmony among national laws by all member countries. However, the most important thing is how member countries create sound diplomatic measures to make the agreement more effective and efficient in combating transnational crime.
\end{abstract}

Keywords: the ASEAN economic community, harmonization of laws, mutual legal assistance, transnational economic crime.

\section{INTRODUCTION}

The development of crimes and economic activity are two factors that cannot be separated from each other. Each of them may influence the other. On the one hand, economic activity is one of the motives or causes for a certain crime, while on the other hand, crime, especially economic crime, may harm economic activity. It cannot be argued that economic activity plays an important faction in the increase of crime rates. $\left[^{1}\right]$
In the meantime, the development of society also resulted in increasingly high mobility of human movement across the national borders and gave birth to globalization in all fields of life. Globalization is a process of international integration, and its development is due to an increased exchange of products and services at a global level and the influences of other aspects related to the cultural and social environment. $\left[{ }^{2}\right]$ On the other hand, globalization has also impacted a new dimension of crimes. It means that the crime is not only limited to 
a national border. Transnational economic activity has also brought an impact on the growth of transnational crime. It also means that crime cannot only be understood through the concept of sovereignty. The process of globalization, the formation of economic integration that covers neighboring countries, such as the European Economic Community (EEC) and ASEAN Economic Community (AEC) has also resulted in a new dimension of crime. The dark side of globalization is that it has given rise to a complex network of illicit markets, including trafficking of arms, drugs, human organs, smuggling, prostitution, slavery, and cybercrime such as child pornography. ${ }^{3}$

The establishment of economic integration or a single market such as AEC aims to increase the region's prosperity as written in the ASEAN Declaration. $\left.{ }^{4}\right]$ In its history, the establishment of AEC has transformed ASEAN into one of the largest markets with a value of 2.400 trillion US dollars. In the meantime, such a big potential will create the opportunity to increase the welfare of the people of the region, and at the same time, cause challenges and threats. ${ }^{5}$ One of the severe threats is the prevalence of transnational crime, especially related to economic activity. This trend cannot be separated from the global phenomenon of transnational crime, which came after globalization and free trade. $\left[{ }^{6}\right]$

To anticipate the threat, ASEAN members should also strengthen cooperation in the field. For that purpose, each member county must cooperate in legal matters through Mutual Legal Assistance. Mutual assistance in criminal matters is a process by which states seek and provide assistance in gathering evidence for use in criminal cases. ${ }^{7}$ ASEAN has agreed and signed with the Treaty on Mutual Legal Assistance in Criminal Matters (ASEAN MLA) and all ASEAN members have signed it in a meeting in Myanmar in 2006. Indonesia has also ratified the agreement in 2008 through Law No. 15 of 2008 concerning the Ratification of the ASEAN Treaty on Mutual Legal Assistance in Criminal Matters. For all transnational crimes, what is imperative is that nations do not act alone but cooperate through employing methods tailored to the crime in question. $\left.{ }^{8}\right]$

Even though its member countries have fully ratified ASEAN MLA, it has not been optimally applied in fighting Transnational Crime. The National Bureau for National Development of Indonesia (BPPN) proved that the application or request for legal assistance is relatively low. Since 2008, for example, Indonesia only applies four requests. In the meantime, Indonesia has accepted 26 requests from other countries through MLA. $\left[{ }^{9}\right]$ Therefore, there should be efforts to optimize MLA by each contracting country, especially by providing a harmonized and synchronic legal framework on MLA to combat transnational economic crime. This article discusses how Indonesia develops harmonization of laws regarding MLA in fighting transnational crime in ASEAN Countries.

\section{RESEARCH METHOD}

The research applies normative legal study, especially comparative legal study between Mutual Legal Assistance laws at the national and international levels. The research also applies the content analysis of laws at the national and international levels on Mutual Legal Assistance in Criminal Matters. The data or sources are collected through library research, especially secondary sources, such as books and articles.

\section{FINDINGS AND DISCUSSION}

\subsection{Transnational Crime and Economic Activity}

The correlation between crime economic activity has long been the subject of study in economics and criminology. It also believes that on one hand, economic activity is one of the causes, and on the other hand, crime may influence economic activity. Becker suggests that a useful theory of criminal behavior can be dispensed with special theories of anomie, psychological inadequacies, or inheritance of special traits and simply extend the economist's usual analysis of choice. $\left[{ }^{10}\right]$ Later, some scholars have developed studies on crime and economic activity. Mulok found that there is strong evidence of long-run co-integration on the impact of economic growth towards crime. In the long run, it was found to be positive and statistically significant. In the short run, bidirectional causation between crime and economic growth was also found to be significant. Eventually, this study is consistent with the economist arguments that good economies tend to create more crime, and the opposite occurs during bad economies. $\left.{ }^{11}\right]$ On the other hand, Rio's study shows that increases in the criminal presence and violent crime reduce economic diversification, increased sector concentration, and diminished economic complexity.[12] These crimes undermine local and national economies, destroy the environment, and jeopardize the public's health and well-being. $\left[{ }^{13}\right]$ 
The development of the economy has also brought an impact on a new type of crime. In anticipating such phenomenon, the United Nations held the fifth UN Congress on Prevention of Crime and Treatment of Offenders 1975 that addressed the Economic and Social Consequences of Crime in 1975. In the meantime, criminology has also identified a new crime related to economic activity. Sutherland, for example, introduced the term corporate crime. It is also known with other similar terminologies such as organized crime and whitecollar crime. However, one of the terminologies that may be properly used is an economic crime. $\left[{ }^{14}\right]$

There are some difficulties in finding a legal definition of economic crime because criminal policy especially related to the economy is different across states. $\left[{ }^{15}\right]$ It is also difficult to provide a thorough impression of economic crime. Crimes that apply technology such as the internet, bank, and other financial instruments are still prevalent. In general, the concept of economic crime may be understood as crimes to achieve monetary advantages. Economic crime refers to acts that violate (illegal) done by individuals or groups that result in financial or professional activities. Some examples are cybercrime, tax evasion, smuggling, drug, and trafficking. ${ }^{16}$

The development of globalization in economic activity has also affected crimes in which crime is limited to one national territory and crosses borders. It is called transnational crimes. That is why United Nations, through its organ, The Organization for Economic Co-operation and Development (OECD), has warned about the threat of transnational crimes. OECD, for example, has also reported that a study on transnational crimes in some parts of the world in 2013 has reached the values of $\$ 3.75$ million. $\left[{ }^{17}\right]$

For ASEAN, OECD reported that the smuggling of controlled products from ASEAN to the United States and European Union reached \$1.55 million, while transnational crimes in ASEAN territory itself reaches US\$90 million. The amount is twice as much as Myanmar's GNP and eight times the bilateral agreement between member countries. $\left[{ }^{18}\right]$

To combat transnational crimes, OECD has issued four recommendations: to establish a normative framework; to establish a normative network; to build and increase technical capacity, and to expand regional partnerships.

The key element in combating transnational crime is a strong legal at national, regional, and international level. There is a vital need to establish an overall strategy at the regional level, review and develop connected strategies at individual national levels to ensure cooperation mechanisms to be utilized beyond venues of discussion. The next step for the region is to turn the recognition of the problem of transnational crime into a strategy or strategies, with associated plans containing tangible actions and results. ${ }^{19}$

\subsection{The Role of Mutual Legal Assistance}

The fighting against crime needs a lengthy procedure in criminal justice. One problem in enforcing the law is when a crime involves a foreign element. Therefore, there should be international cooperation. Without cooperation, the process will not be successful. $\left[{ }^{20}\right]$ In the international law regime, there are some international agreements on MLA, such as Convention on Transnational Organized Crime (TOC) and G20 countries that have provided a legal foundation and framework to fight transnational crimes through MLA. In G20 for example, it is regulated that contracting parties should accept an effective regulation as the basis for the implementation of MLA; establish an effective institution; develop speed mechanism in response to a request for MLA; provide good coordination and cooperation between jurisdictions based on each national legal system, and exchange the information internationally through various mechanisms based on each national legal system. $\left[{ }^{21}\right]$

MLA is the formal process by which one country requests another country to exercise its coercive powers or to take steps to obtain evidence that must be admissible in a criminal trial. Meanwhile, ASEAN MLA has also provided a legal framework that reflects the willingness and common aspiration to increase the effectiveness in combating transnational crime. It has also shaped to some extent on prevention, investigation, and trial of a transitional crime. $\left.{ }^{[22}\right]$ Indonesia has ratified the related convention through Law No.1 of 2006 but still faces some obstacles in implementing that Treaty, especially in its legal principles. The differences in member countries' legal systems, for example, in understanding the dual criminality principle, have become a major obstacle to implement the Treaty. That is why OECD recommended that there should be better coordination in legal enforcement agencies between different legal systems. $\left.{ }^{23}\right]$ However, at a regional level, this is evidenced through the Association of Southeast Asian Nations (ASEAN) efforts, which have created the ASEAN PoliticalSecurity Community Framework aimed to facilitate 
and strengthen political and security cooperation within member States. $\left[{ }^{24}\right]$

Cooperation on MLA has been initiated in several meetings regarding cooperation in combating crime. Indonesia has initiated an effort to combat transnational crime in Indonesia through bilateral agreements for a long time. In its practice, there are some models of international cooperation in solving criminal problems such as extradition agreement, cooperation on MLA, and agreement on transferring information in a legal proceeding. $\left[{ }^{25}\right]$ Indonesia has built initiative on solving criminal issues through a bilateral agreement, such as with Malaysia. Through bilateral agreement, Indonesia reached an agreement on extradition through Law No. 9 of 1974. An agreement with Philippine in 1976 then followed the initiative. In the long run, Indonesia has signed an agreement on MLA with Australia, China, India, Hong Kong, Korea, Uni Arab Emirates, Vietnam, and Switzerland.[ $\left.{ }^{26}\right]$ To implement all agreements, Indonesia has issued Law No. 1 of 2006 regarding Mutual Legal Assistance in Criminal Matters, while in the multilateral or regional endeavor, Indonesia ratified the ASEAN Treaty on Mutual Legal Assistance in Criminal Matters in 2008 with Law No.15 of 2008. With ratification, Indonesia has bound itself to adopt all of the ASEAN MLA agreements in 2004.

Law No. 1 of 2006 as the primary source of MLA regulates some principles. First, the MLA coverage is in investigation, prosecution, trial in line with the regulation of the requested country. MLA does not include the execution of court decisions. The assistance is just related to administrative effort, not related to detention and arrest. Confiscation of assets just related investigation authority is not related to the court decision. Second, there is a special clause. They are related to extradition and transfer of people, arrest, and detention for extradition or transfer. Third, all legal assistance should respect the reciprocity principle. The problem is whether all other countries will similarly apply this principle. $\left[{ }^{27}\right]$ In practice, each country will ask for the same treatment while the condition may be different. Therefore, the reciprocal principle must be supported with good faith principles by other countries.

An exceptional clause in Law No. 1 of 2006 consists of mandatory refusal and discretionary refusal. Mandatory refusal is based on political crime except for murder or attempts to murder the head of state or government and terrorism based on martial law. Other reasons are double jeopardy, unprosecuted crime, the violation of the non- discrimination principle, national interest, and misuse of legal assistance for another purpose. Discretionary refusal is the implementation of the dual criminality principle. The crime charged with the death penalty request will disturb Indonesia's legal process and burden Indonesia assets. The implementation of an exceptional clause will be a barrier for the international Treaty, and it commonly practiced now and maybe in the future. $\left[{ }^{28}\right]$

\subsection{Indonesia Endeavour in Harmonizing Laws on MLA}

The priority in harmonizing regulation on MLA is how to set up similar coverage of all regulations. According to Law No. 1 of 2006, the coverage of MLA is in investigation, prosecution, and hearing in the trial. While in ASEAN MLA the coverage is investigations, prosecutions, and resulting proceedings. Therefore, both regulations have nearly the same coverage. It also means that both regulations do not cover assistance related to the execution of court decisions, especially assistance in the stage of assets recovery. While in a legal process, execution of court decision is the most important stage especially in economic crime, to bring back the accessed result from crime. Therefore, the coverage of MLA agreement should be included both in national or international law.

One important clause in the ASEAN MLA of 2004 is the principle that the requested party shall respond as soon as possible to reasonable inquiries by the Requesting Party, while Law No. 1 of 2006 does not adopt this principle. This principle has been incorporated in Indonesia's Criminal Law Procedure, Law No. 8 of 1981 Criminal Law Procedure. Thus, this principle should be adopted in Law No. 1 of 2006.

Another clause that should be harmonized is the exception or non-applicability clause. In law No. 1 of the 2006 exception clause regulated in art. 4. It says that MLA should not cover the extradition, detention, and arrest for extradition, prisoner transfer, and transfer of the case. In ASEAN MLA 2004, the principle of non-applicability regulated in art. 2 . It covers the arrest or detention of any person with a view to the extradition of that person. It also includes enforcement in the requested party of criminal judgment imposed in the Requesting Party except to the extent permitted by the law of the requested party. It even mentions the transfer of persons in custody to serve sentences and the transfer of proceedings in criminal matters.

Both Law No.1 of 2006 and ASEAN MLA have nearly the same regulation on exceptional 
clauses. While in Malaysian MLA, the exceptional clause says that this Act does not authorize the extradition of the arrest or detention with a view of extradition, of any person. It means that Malaysian law has less reason for an applicability clause.

\subsection{Legal Problem in Enforcing Agreement on $M L$}

Law, so does an international agreement, as a social system has some requirements to achieve its goals. Any legal system covers legal substance, legal structure, and legal culture that influence its enforcement. $\left[{ }^{29}\right]$ However, international agreement as a legal norm follows the principle of pacta sunt servanda. An international agreement that involves high political officials should be designed optimally to achieve its goal. Designing international agreements involves a multi-level political process. Agreements are most likely to be successful when there is real political buy-in in advance. Thus, it is important to negotiate a new agreement to build up a high degree of consent early on. Without political buy-in, a good design agreement will founder. $\left[{ }^{30}\right]$

An international agreement also needs some conditions in the stage of its enforcement and after the enforcement. Assessment of an international agreement's success at this post-negotiation stage involves two concerns: (i) how relevant actors implement and comply with agreements; and (ii) how implementation and compliance are enforced and monitored. Factors affecting implementation and compliance include domestic's politics and information sharing. Therefore, the pre-condition, implementation, and evaluation are separated factors in the implementation of an international agreement.

Another crucial issue in the enforcement of MLA is the dual or double criminality which generally means that the crime requested for legal assistance should be recognized as a crime according to the requesting and requested party. $\left[{ }^{31}\right]$ The principle of double criminality is traditionally bound with institutions of international criminal law. Double criminality is a requirement not only with extradition but also with the transfer of criminal proceedings and with the execution of foreign sentences. International criminal law employs a range of "double conditions," the common denominator of which is the requirement that two legal systems share a certain set of values or legal prescriptions.

For Indonesia, the submission of an MLA request must be based on a decision that has a final and binding decision, especially related to the execution of a decision. In Indonesia's justice system, complete decisions cannot be obtained immediately and must wait for a sufficiently long period. Besides that, requests for asset execution are difficult because various countries stipulate that asset execution abroad must be based on a court decision clearly stating the assets to be executed. Meanwhile, Indonesian law enforcers still have difficulty tracing the assets of a convicted person abroad. For this reason, Indonesia needs to increase the capacity and capability of law enforcement in asset tracking and build cooperation with various other countries. Due to these various obstacles, the request for MLA from other countries in ASEAN countries, including Indonesia, is still deficient. The UNDOC's review revealed that the total MLA applications since 2005 were only 75 cases. The request was addressed to Malaysia in 9 cases and to Singapore in 63 cases, while other countries did not receive any requests for assistance. Meanwhile, ASEAN countries' requests were only 21 cases, 16 of which were submitted by Malaysia and 5 by Singapore. In contrast, Indonesia did not submit any request for legal assistance.

Another legal constraint related to the Central Authority (central authority) in Indonesia is in the hand of the Ministry of Law and Human Rights. In the justice system and law enforcement, the Ministry of Law and Human Rights is not directly related to the judicial process such as arrest, detention, and trial. Whereas in many other countries, the authority holds by the Attorney General's Office is directly related to law enforcement. In Singapore, for example, the central authority in MLA is in the Criminal Justice Division of the Singapore Attorney General's Chambers, which plays an important role in the process of mutual assistance cooperation. However, this should not be an obstacle as long as the function is only for administrative purposes because technical matters still exist in their respective institutions such as the police, prosecutors, or other special investigators. This problem can also be anticipated by the formation of a task force occupied by officers who have the skills and experience from various related institutions.

From practical experience, Indonesia seems to have not yet optimally utilized the existence of the MLA agreement. A report from the National Legal Development Agency (BPHN) in 2014 showed that Indonesia received more requests for the MLA Agreement than submitted an MLA Agreement to other countries. From 2008 to 2013, Indonesia had received 26 MLA requests from ASEAN countries while Indonesia only filled four requests. This shows that Indonesia is not very active in submitting MLA 
to other countries while quantitatively it is known that Indonesia has many cases that must be resolved through MLA. ${ }^{32}$ The next problem is related to the execution of a court decision on assets of prisoners abroad, especially related to banking secrets because most countries are very strict in implementing bank secrecy. $\left[{ }^{33}\right]$

In an agreement between Indonesia and Australia dual criminality would not be a problem since in the Annex to the Treaty; 35 types of crime can be request or legal assistance. While in an agreement between Indonesia and China there is an exceptional clause that is not regulated. It means the applicability depends on the requested country. The exception is largely formulated. Art. 1 para. (2) The agreement says: "For this Treaty, criminal matters refer to any act or omission constituting an offense with the respective national law of the parties." It means the applicability depends on the requested country.

There are differences in its regulation in agreement with South Korea if it is compared with an agreement with Australia and China. The coverage of the agreement with South Korea also includes the process of prosecution. It says that the criminal matters mean investigations, prosecutions of proceedings relating to any offense of which at the time of the request for assistance. It also falls within the jurisdiction of the competent authorities of the request for assistance, falls within the jurisdiction of the competent authorities of the Requesting Party.

There are also differences in the crime as the object of MLA. In agreement with Australia, the crime as the object of MLA is limited to the crime prescribed in the annex of the agreement. In agreement with China, the object of the crime is based on the dual criminality principle. While in the agreement with South Korea, the crime is based on the jurisdiction and competent authorities requesting party. The Criminal matters is also enlarged to matters related to offenses against a law on taxation, customs duties, foreign exchange control, or other revenue matters, but not in connection with non-criminal proceedings relating thereto. It means that the object of MLA is based on the jurisdiction requesting party or requested party. However, the agreement can also be associated to certain crimes, especially related to transnational economic crime. Therefore, this agreement will be more applicable in anticipating a transnational crime in the era of globalization and not limited to just traditional crime.

However, despite some barriers and limitations of the rule in MLA, which may limit the type of crime that becomes the object of the request, the most important is the will of each party to optimize the enforcement of the agreement made. Even though there are some limitations due to national interest, the flexibility in its implementation will be useful as long as the request will not damage the interest of the requested party. Therefore, the principle of the best interest to both parties will help achieve the goal of the agreement.

\section{CONCLUSION}

Regulation on Mutual Legal Assistance in Criminal Matters is urgent in combatting transnational crimes, especially in economic crimes. The regulation exists both in national and international law regimes. At the national level, it was regulated in Law No. 1 of 2006, while at the international level, Indonesia has signed both bilateral and multilateral agreements. Indonesia has ratified ASEAN Treaty on Mutual Legal Assistance in Criminal Matters through Law No. 5 of 2008. The bilateral agreement has been signed with several countries such as Australia, China, India, Hongkong, Korea, Uni Arab Emirates, and Vietnam. In principle, there is no crucial difference among those regulations. However, harmonization and synchronizations are still required to make those agreements more applicable, such as provision on non-applicability, the principle of dual criminality, and procedural clauses. Only then could it be implemented optimally in combating transnational crime. Harmonious and synchronize regulation will help to combat transnational crime at an international level. In turn it will bring provide for good atmosphere economic activity among AEC. There are also some legal handicaps in bilateral agreements made by Indonesia, especially in the coverage of the agreement, exceptional clause, and the adoption of dual criminality. Such clauses may become obstacles in facing new emerging transnational crime and it will resulted in threath in achieving the objectives of ASEAN Economic Community. However, political consideration will always become the primary consideration in responding to any legal assistance application by one country.

There should be an enlargement of international cooperation both on the bilateral and multilateral levels on MLA. The most important thing is that there should be efforts to improve harmonization and synchronization between national and international agreements and international agreements themselves. Those efforts should be reached through sound diplomatic measures to make 
the agreement more effective in combating transnational crime to achieve the goal of ASEAN Economic Community.

\section{REFERENCES}

[1] Asif Islami, "Economic Growth and Crime against Small and Medium Sized Enterprises in Developing Economies", The World Bank Development Economics Global Indicators Group, Washington DC, Working Paper, 6768, February 2014, [Online]. Available: https://openknowledge.worldbank.org/handl e/10986/17306.

[2] Marius-Răzvan Surugiu, and Camelia Surugiu, "International Trade, Globalization, and Economic Interdependence between European Countries: Implications for Businesses and Marketing Framework", Procedia Economics and Finance 32 (2015). [Online]. Available: https://www.researchgate.net/publication/2884 16281_International_Trade_Globalization_and _Economic_Interdependence_between_Europe an_Countries_Implications_for_Businesses_an d_Marketing_Framework.

[3] Nafiu Ahmed, "The Effect of Globalization: Terrorism and International Crime". IOSR Journal of Business and Management 8. Vol. 18, Issue 11. Ver. III (November. 2016), [Online].Available from: https://www.researchgate.net/publication/3299 44504 The Effect of Globalization_Terroris $\underline{\mathrm{m} \text { and International_Crime\#fullTextFileCont }}$ ent [accessed Oct 07 2020].

[4] Jamil Maidan Flores and Jun Abad, "The Founding of ASEAN", [Online]. Availble: http://www.ASEAN.org/ASEAN/ab out-ASEAN/history/

[5] https://www.usASEAN.org/why-ASEAN/whatis-ASEAN, accesed 21 January 2016

[6] Cesar Alvarez. (2015). The ASEAN Economic Community and the Fears of an Organized Crime Boom, , 2015, [Online]. Available:t www.asistrategis.org.au/the-ASEAN, accessed 20 Oktober 2018.

[7] Kimberly Prost, International Cooperation in Combating Transnational Crime, Information Exchange Network for Mutual Asssitance in Criminal Matter, 1989 [Online], Available: https://www.oas.org/juridico/mla/en/can/en_ca n_prost.en.html Accessed, Oktober 2020 .

[8] James N. Mitchell. (2016). "Transnational Organized Crime in Indonesia - the Need for
International Cooperation", , Brawijaya Law Journal. vol. 3, no. 2, p. 194, DOI: http://dx.doi.org/10.21776/ub.blj.2016.003.02. 05 .

[9] Badan Perencanaan Pembangunan Nasional, Evaluasi Peran Otoritas Pusat dalam Pelasanaan Bantuan Hukum Timbal Balik. Jakarta, BPPN, 2014.

[10] Eide Erling, Paul H. Rubin, and Joanna M. Shepherd, Economics of Crime. Research Paper, Emory University School of Law, 2014, [Online] Available: at http://ssrn.com/abstract=1912073, Accessed, 15 January 2019.

[11] Dullah Mulok, Mori Kogidb, Jaratin Lilyc, Rozilee Asid, "The Relationship between Crime and Economic Growth in Malaysia: ReExamine Using Bound Test Approach," Malaysian Journal of Business and Economics vol. 3, no. 1, 2016, [Online], Available: https://www.researchgate.net/publication/3097 37921 The Relationship between_Crime an d_Economic Growth_in Malaysia_ReExamine Using Bound Test_Approach [accessed Oct 07 2020].

[12] Viridiana Ríos, "The I mpact of Crime and $V$ iolence on Economic Sector Diversity, [Online], Available: https://scholar.harvard.edu/files/vrios/files/rios v_crimesectordiversitydec212015.pdf. P.11

[13] Cunning May, Transnational Crime and the Developing World. Washington DC, Global Financial Integrity, 2017.

[14] Supanto, Kejahatan Ekonomi Global dan Kebijakan Hukum Pidana, Bandung, Alumni, 2010.

[15] John E. Conklin, Criminology Fourth Edition. New York, Macmillan Publishing Co, 1992.

[16] Abud Al-Sarraj, 2005 2005, The Concept of Economic Crimes As Perceive across the world, Typology, New Trends and Countermeasures, Papers presented at Eleventh United Nations Congress on Crime Prevention and Criminal Justice, Bangkok, April 2005, [Online], Available: www.unafei.or.jp/english/.../18Presentation _1.pdf 
[17] Haken, Jeremy. Transnational Crime in the Developing World, Research Report, the Global Financial Integrity, February 2011.

[18] Elliot, T. (2012). "Fighting Transnational Environmental Crime", Columbia Journal on International Affairs, November 21st, 2012,( (66), 1 Fall/Winter 2012.

[19] UNODC. Transnational Organized Crime in Southeast Asia: Eevolution, Growth and Impact, Bangkok: UNODC Research.

[20] I. Wayan Patiana, Hukum Pidana Internasional. Bandung, CV Irama Wydia. 2006.

[21] G20 High- Level Principles of Mutual Legal Assistance, https://star.worldbank.org

[22] Baizura Kamal, International al Cooperation: Mutual Legal Assistance and Extradition, 2014[Online], Available: http://www.unafei.or.jp/english/pdf/PDF_GG6 Seminar/05-4_Malaysia.pdf,

[23] OECD, Typology on Mutual Legal Assistance in Foreign Bribery Cases [Online], Available: http://www.oecd.org/daf/antibribery/TypologyMLA2012.pdf 2012, accessed on 2 December 2019.

[24] Adi Kusumaningrum, "The ASEAN PoliticalSecurity Community: ASEAN Security Cooperation on Combatting Transnational Crimes", Indonesian Journal of International Law. vol.11, no. 1, p. 91. 2013,

[25] Azhari Setiawan, “ASEAN 'Political-Security' Community: Kerjasama Multilateral \& Mutual Legal Assistance dalam Menangani Kasus Money Laundering di Asia Tenggara”, Jurnal Integritas: Anti Korupsi. vol. 2, no. 1, 2016, DOI: https://doi.org/10.32697/integritas.v2i1

[26] Anna Christina Sinaga, et al., "Mutual Legal Assistance to Sthrengthen Indonesia-ASEAN Forrest Governance", Cifor Org. Infor Brief, no. 77, Augustus 2014. [Online]. Available: https://www.cifor.org/library/5405/

[27]Francesco Paris and Nita Ghei, "The Role of Reciprocity in International Law", Cornell International Law Journal, vol. 36, Issue 1, Spring 2003, p. 120, [Online]. Available: https://scholarship.law.cornell.edu/cgi/viewc ontent.cgi article $=1509 \&$ contex $t=c i l j$

[28] UNODC. NY, USA. Manual on Mutual Legal Assistance and Extradition, High- Level Principles of Mutual Legal Assistance, 2012. September 19 [Online]. Available: https://star.worldbank.org.

[29] Lawrence M. Fiedmann, The Legal System: A Social Science Perspective, (Translation by M. Khozim), Bandung, Nusamedia, 2011.

[30] Emily O'Brien and Richard Gowan. (2012). What Makes International Agreements Work: Defining Factors for Success, Center for International Cooperation, New York University, [Online]. Available: https://cic.nyu.edu/sites/default/files/gow an_obrien_factors_success.pdf.

[31] ICJ, Transnational Injustices National Security Transfers and International Law, Executive Summary ICJ, Geneva, Switzerland, 2017. [Online]. Available: https://www.icj.org/wpcontent/uploads/2017/09/Europe-

Transnational-Injustices-ExecSummaryPublications-Reports-Thematic-reports-2017ENG.pdf, accessed 2 Sptembe 2020

[32] Badan Perencanaan Pembangunan Nasional, Evaluasi Peran Otoritas Pusat dalam Pelasanaan Bantuan Hukum Timbal Balik. Jakarta, BPPN, 2014.

[33] Siswanto Sunarto, Ekstradisi dan Bantuan Hukum Timbal Balik dalam Masalah Pidana, Instrument Penegakan Hukum Internasional, Jakarta, Rineka Cipta, 2009. 